\title{
ON DEVELOPING MATERIALS FOR CLIL
}

\author{
Ivana Cimermanová \\ University of Presov Faculty of Arts, Institute of British and American Studies, Slovakia
}

\begin{abstract}
Content and language integrated learning (CLIL) is not an unknown term. In Slovakia, many schools communicate they apply CLIL methodology; however, there are numerous studies that are sceptical about CLIL application. The most significant problem defined by CLIL teachers is the lack of appropriate materials that follow dual aims. Based on this feedback the development of CLIL materials became a part of pre-service teachers' methodology courses. The present study aimed to explore the attitudes of the pre-service teachers towards the possible application of the content and language integrated learning in their teaching. Questionnaires and pre-service teachers' portfolios provided data from 63 participants. The study also presents the results of discussions on the problems faced by students, the attitudes of student teachers towards material evaluation and development, planning CLIL lessons and the analysis of the questionnaire focussing on students' attitudes towards CLIL application. Data suggest that even though pre-service teachers are positive about CLIL application and are interested in doing CLIL lessons they do not feel confident especially in evaluating the outcomes of CLIL lessons and creating materials for CLIL lessons. Finally, the author summarises the pedagogical implications to pre-service teachers study programmes as well as recommendations for teaching practice.
\end{abstract}

Keywords: content and language integrated learning, developing materials, feedback, Likert scale, qualitative study.

\section{Introduction}

Content and language integrated learning (CLIL) is not a new term. It is, however, probably still more discussed than applied even though the existing body of research on CLIL suggests there are different benefits of CLIL observed (e.g. learners' thinking and content learning (Jäppinen, 2005; Cañado, 2018; Quazizi, 2016; Chostelidou \& Griva, 2014), pluriliteracy (Isidro \& Lasagabaster, 2018), vocabulary acquisition (Alsonso, 2015), developing reading skills (Chostelidou \& Griva, 2014), oral communication skills (Agudo, 2019), creating a highly motivational atmosphere (Quazizi, 2016)).

Besides the positive effects mentioned above, we have to state there are studies bringing also contradictory empirical evidence (Piesche, Jonkmann, Fiege, \& Keßler, 2016; Bruton, 2013). CLIL teachers often mention they do not feel confident in language use and/or subject content. They (both, language and subject teachers) also claim there is a lack of CLIL materials (communicating 
content at adequate language proficiency). The international research realised in 4 countries (Italy, Portugal, Romania and Poland) also identifies the lack of CLIL designed materials as the main critical aspect (C4C - CLIL for Children, 2016). L. Vilkanciné \& I. Rozgiené based on their research experience claim that „despite the fact that teachers are critical about their linguistic competences, they appreciate CLIL as an opportunity to both develop their linguistic competences and enhance professionalism in the content area“.

Using CLIL means "reconceptualization of language from language learning per se towards an integrated model which actively involves the learner in using and developing language of learning, language for learning and language through learning” (Coyle, 2007, p. 545).

In case schools want to apply CLIL they need teachers who understand the principles of CLIL and are ready to cooperate, collaborate and to create the material that reflects the dual aims reflecting the students' needs. The present study addresses the question of the attitudes of the pre-service teachers towards the possible application of the content and language integrated learning in their teaching. The study seeks to obtain data which will help to address the problems defined by the pre-service teachers in the curriculum innovation. The data are collected (1) from the students' portfolios tracking their attitudes 4 times during the study, (2) questionnaire and (3) discussions with students.

\section{Content and language integrated learning}

The term content and language integrated learning (abbr. CLIL) was and is understood very broadly and has been developed and evolved during time. Some researchers and practitioners perceived it as a synonym to bilingual education, other as a result of integrated language teaching, content-based instruction (see e.g. Zarobe \& Cenoz, 2018; Canado, 2016). Probably, it is mostly defined as an umbrella term for both, learning the content subject through the medium of a foreign language and learning a foreign language by learning a content-based subject. S. Darn (2006) states that "The evolution of CLIL involves precedents such as immersion programmes (North America), education through a minority or a national language (Spain, Wales, France), and many variations on education through a "foreign" language".

P. Mehisto (2012) defines CLIL as "a dual-focused teaching and learning approach in which the L1 (first language) and an additional language or two are used for promoting both content mastery and language acquisition to pre-defined levels“. D. Coyle et al. (2010, p. 4) describe CLIL as ,an approach which is neither language learning nor subject learning, but an amalgam of both and is linked to the processes of convergence. Convergence involves the fusion of elements which may have been previously fragmented, such as subjects in the curriculum”. It is 
important to realise the "symbiosis" of the two as one of the ways to make language learning meaningful, to let students use language and not only to learn a language. D. Marsh \& M. Frigols-Martín stress that „CLIL does not necessarily correlate with the maximum exposure hypothesis (the more you have the better you become)".

Frequently, learners, teachers, parents decision makers raise the question what the aim of CLIL application is and they expect to receive a straight and clear answer. This is, however not so simple. David Marsh in an interview for IH Journal of education and development (Scott, 2009, p.5) claims "The aims depend on the model used. These may be subtle, as in helping youngsters understand the point of learning a language and developing in the youngsters a positive 'can do' attitude towards themselves as language learners". Concerning the main advantages he highlights the "positive attitude changes in learners towards learning a language, and towards themselves as language learners".

Here it is important to say that due to a broad definition there are various models bringing different results. M. Canado (2016, p.14) discusses the controversy in CLIL implementation and suggests that "criticism has recently been leveled at CLIL due to the plethora of models or variants which can be identified within it" what is partly the result of a broad definition.

Speaking about the Slovak context, CLIL is generally positively perceived, but still mostly applied by individuals. Based on her research S. Pokrivčáková (2013) states that teachers express concerns about (1) how to prepare CLIL classes, (2) how to make it compatible with both subject and language aims and standards, (3) what to assess. She also observed that teachers defined (4) lack of suitable CLIL materials and (5) the struggle to find a balance between language and content objectives as the week aspects of CLIL application.

\section{(Content and language integrated learning) Material development}

English as a foreign language (EFL) is taught worldwide as a lingua franca. This results in a rich and varied market with textbooks and thus teachers can choose the textbook to meet students' needs, teacher's requirements, aim and methods. We are really 'privileged' compared to other academic subject where usually no more than two or three titles are offered if not less. What more, the EFL textbooks are, as a rule, accompanied not only with a workbook and teacher's guide, but teachers can use supplementary materials as audio/video recordings, dictionaries, test booklets, IWB materials, special handouts, digital content with interactive activities, dyslexia-friendly materials, portfolios that allow to build learner autonomy, flashcards, posters etc. The textbooks cover global issues, cross-curricular topics, CLIL parts and still there are teachers who feel the need 
to create their own materials, to "tailor" them to the learners' needs from various reasons.

P. Mehisto (2012, p.16) stresses that "Quality learning materials do more than just communicate information. They promote critical and creative thought, discussion and learner autonomy”. S. Ranjit (2000) suggests the following steps to develop learning material (1) Identification of problem and need, (2) Analysis of the problem (Resistance pattern, Identification of need and motivating factors, Persuasion tactics), (3) Objective setting, (4) Selection of the topics, (5) Format selection, (6) Content arrangement, (7) Editing, (8) Testing and (9) Revision.

B. Tomlinson (2010) focusing on foreign language teaching specifically and discussing developing language learning materials enumerates the following principles of material development:

1. Provide many opportunities for the learners to produce language in order to achieve intended outcomes.

2. Make sure that these output activities are designed so that the learners are using language rather than just practising specified features of it.

3. Design output activities so that they help learners to develop their ability to communicate fluently, accurately, appropriately and effectively.

Majority of teachers create their own materials, at least from time to time, and have experience how to structure and organise it, how to make it meaningful and practical at the same time. Creating CLIL materials is for many teachers a new issue. This is also true about novice teachers and pre-service teachers who have no or just little experience with material development.

P. Mehisto (2012, pp.17-25) enumerates 10 criteria of quality CLIL materials: (1) make the learning intentions (language, content, learning skills) \& process visible to students, (2) systematically foster academic language proficiency, (3) foster learning skills development and learner autonomy, (4) include self, peer and other types of formative assessment, (5) help create a safe learning environment, (6) foster cooperative learning, (7), seek ways of incorporating authentic language and authentic language use, (8) foster critical thinking, (9) foster cognitive fluency through scaffolding of a) content, b) language, c) learning skills development helping student to reach well beyond what they could do on their own, (10) help to make learning meaningful.

What more CLIL material designer has to consider the "second" content subject aim. This is not an easy task and creating and piloting materials can be very demanding. 
SOCIETY. INTEGRATION. EDUCATION

Proceedings of the International Scientific Conference. Volume I, May $22^{\text {th }}-23^{\text {th }}$, 2020. 86-96

\section{Teacher-training and content and language integrated learning in Slovakia}

Even though there have been published studies and reports on CLIL materials in Slovakia (e.g. Pokrivčáková, 2015; Pokrivčáková, Menzlová, \& Farkašová, 2015; Sepešiová, 2015; Straková, 2015) there is still lack of materials, need to prepare own materials. What more, concerning teacher preparation CLIL is a subjects of foreign language teacher preparation (mainly EFL teachers) and rarely if ever the subject of subject content teachers. In Slovakia, most teacher training programmes are studied in combination, they are double major programmes and thus majority of students are being prepared for teaching 2 subjects at secondary level. To my knowledge, there is no Slovak university besides the University in Presov that would introduce CLIL as a compulsory subject for pre-service teachers. It is a topic covered within the methodology syllabus and there are several universities offering CLIL course as a compulsory-optional subject.

Double major pre-service English language teachers studying at the University of Presov can sign for compulsory-optional CLIL course. We observe an increasing interest in the subject. CLIL is a compulsory subject for TEFL single major students. Every year there are approx. sixty EFL (teacher training study programmes) single and double major graduates. They all pass three compulsory methodology courses, 10 weeks teaching practice and they can sign for different methodology oriented courses. During their masters study they work with European Portfolio for Student Teachers of Languages (EPOSTL) that is not only a self-reflection tool but an important source of feedback for the methodology teacher. Students reflect on their skills, competencies, attitudes 4 times during their study (before their teaching practice I, after teaching practice I, after teaching practice II, after teaching practice III). This allows students and teachers to follow their progress and set the new aims. I select 8 descriptors from EPOSTL to present the changing attitudes of student-teachers. The descriptors deals with evaluation of materials, selecting materials, designing materials and CLIL. Students express their attitude on scale 1-100 (usually they use numbers in tens or fives - what leads us to consideration to change the scale to 1-10). Figure 1 displays the results obtained from the analysis of the selected items from 63 portfolios of 20-25 years old TEFL students (see figure 1, table 1) and the numbers are average values of the students measured 4 times in the periods stated above. 


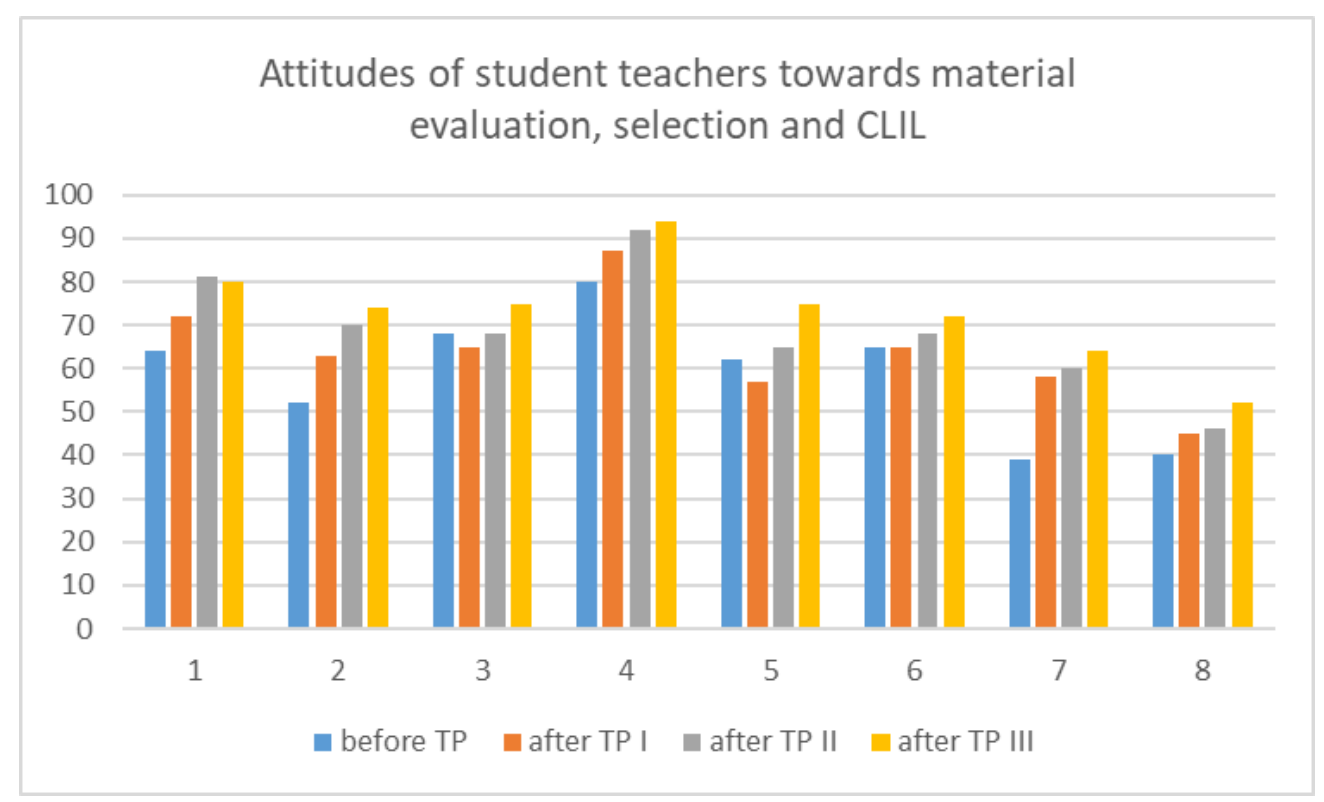

Figure1 Attitudes of student teachers towards material evaluation, selection and content and language integrated learning

Table 1 Legend to the figure 1

\begin{tabular}{|l|l|l|l|}
\hline $\begin{array}{l}\text { Graph } \\
\text { item } \\
\text { no }\end{array}$ & EPOSTL descriptor & $\begin{array}{l}\text { Knowing } \\
\text { proficiency } \\
\text { levels/critical } \\
\text { thinking }\end{array}$ & $\begin{array}{l}\text { Creativity } \\
\text { expected }\end{array}$ \\
\hline 1 & $\begin{array}{l}\text { I can evaluate and select a variety of materials to stimulate } \\
\text { speaking activities. }\end{array}$ & yes & \\
\hline 2 & $\begin{array}{l}\text { I can evaluate and select a variety of materials to stimulate } \\
\text { writing. }\end{array}$ & $\begin{array}{l}\text { yes } \\
\text { materials and activities which awaken learners' interest in } \\
\text { and help them to develop their knowledge and } \\
\text { understanding of their own and the other language culture. }\end{array}$ \\
\hline 3 & $\begin{array}{l}\text { I can locate and select listening and reading materials } \\
\text { appropriate for the needs of my learners from a variety of } \\
\text { sources, such as literature, mass media and the Internet. }\end{array}$ & yes & \\
\hline 5 & $\begin{array}{l}\text { I can design learning materials and activities appropriate } \\
\text { for my learners. }\end{array}$ & $\begin{array}{l}\text { yes } \\
\text { and fan guide learners to produce materials for themselves } \\
\text { and learners. }\end{array}$ & yes \\
\hline 6 & $\begin{array}{l}\text { I can design ICT materials and activities appropriate for } \\
\text { my learners. }\end{array}$ & yes & yes \\
\hline 8 & $\begin{array}{l}\text { I can plan to teach elements of other subjects using the } \\
\text { target language (cross- curricular, CLIL etc.). }\end{array}$ & yes & yes \\
\hline
\end{tabular}

As it can be seen from the figure 1 students underestimate or overestimate (see items no 3, 5 and 6) their abilities before teaching practice, what is a natural 
phenomenon. The graph shows they are relatively confident in locating and selecting materials (e.g. on internet, see item no 4) but on the other hand they feel less confident in designing their own material (see items no 5-7), especially using internet (item no 7). Selected group of students are TP I sign for the course Using ICT in TEFL and this might have influenced the results after TP II and subsequently.

Concerning CLIL issue (item no 8) we divided the group into single (English only) and double major students. We expected that double major students would feel more confident compared to single major students but results proved the opposite (see figure 2).

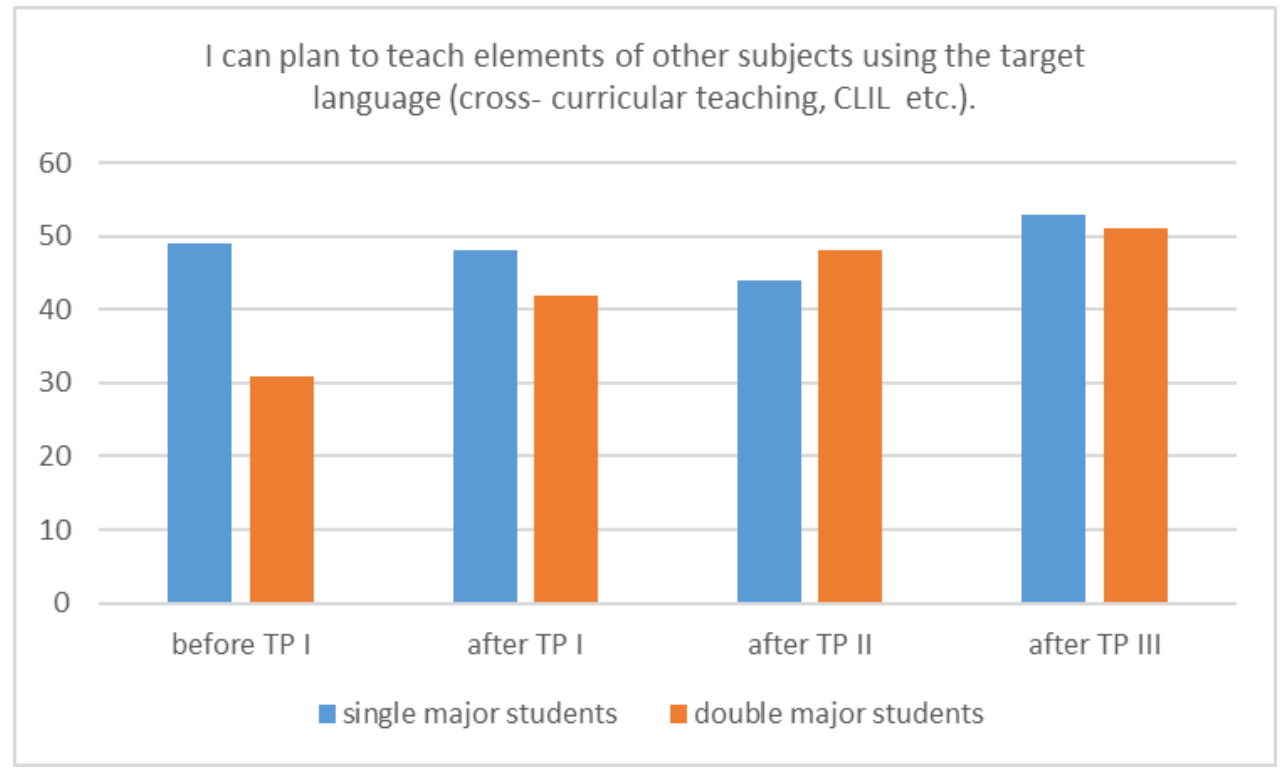

Figure 2 Comparison of the attitudes of single and double major students towards content and language integrated learning lesson planning

We have already mentioned that the single major students pass the CLIL course as a compulsory part of their study programme. This might be one of the reasons why they feel more confident in planning CLIL lesson compared to their double major mates.

As this result was surprising we asked the learners to fill in the questionnaire on their attitudes towards CLIL application. The 5-point Likert scale (strongly agree, disagree, neither agree nor disagree, agree, strongly agree) was used and we split the group of 63 respondents into 2 subgroups (10 single majors (SM) and 53 double majors (DM)). 
Table 2 Questionnaire results

\begin{tabular}{|l|l|l|l|}
\hline & $\begin{array}{l}\text { Mean } \\
\text { (median) } \\
\text { Total }\end{array}$ & $\begin{array}{l}\text { Mean } \\
\text { (median) } \\
\text { SM }\end{array}$ & $\begin{array}{l}\text { Mean } \\
\text { (median) } \\
\text { DM }\end{array}$ \\
\hline $\begin{array}{l}\text { CLIL has positive benefits on subject content } \\
\text { learning. }\end{array}$ & $3,88(4)$ & $4,00(4)$ & $3,86(5)$ \\
\hline CLIL has positive benefits on language learning. & $3,09(3)$ & $3,30(3)$ & $3,05(3)$ \\
\hline CLIL can be applied in groups of young learners. & $3,45(3)$ & $3,90(4)$ & $3,38(3)$ \\
\hline The teacher does not need to be proficient in English. & $3,00(3)$ & $3,20(2,5)$ & $2,96(3)$ \\
\hline $\begin{array}{l}\text { The teacher does not need to be a specialist in subject } \\
\text { content. }\end{array}$ & $3,24(3)$ & $3,00(3)$ & $3,29(3)$ \\
\hline I am interested in realising CLIL lessons. & $4,09(4)$ & $4,20(4)$ & $4,07(4)$ \\
\hline I can design CLIL lessons. & $2,35(2)$ & $2,70(3)$ & $2,29(2)$ \\
\hline I can prepare materials for CLIL lesson. & $2,89(2)$ & $2,30(2)$ & $3,00(2)$ \\
\hline I can evaluate the outcomes of the CLIL lessons. & $1,83(2)$ & $1,90(2)$ & $1,82(2)$ \\
\hline
\end{tabular}

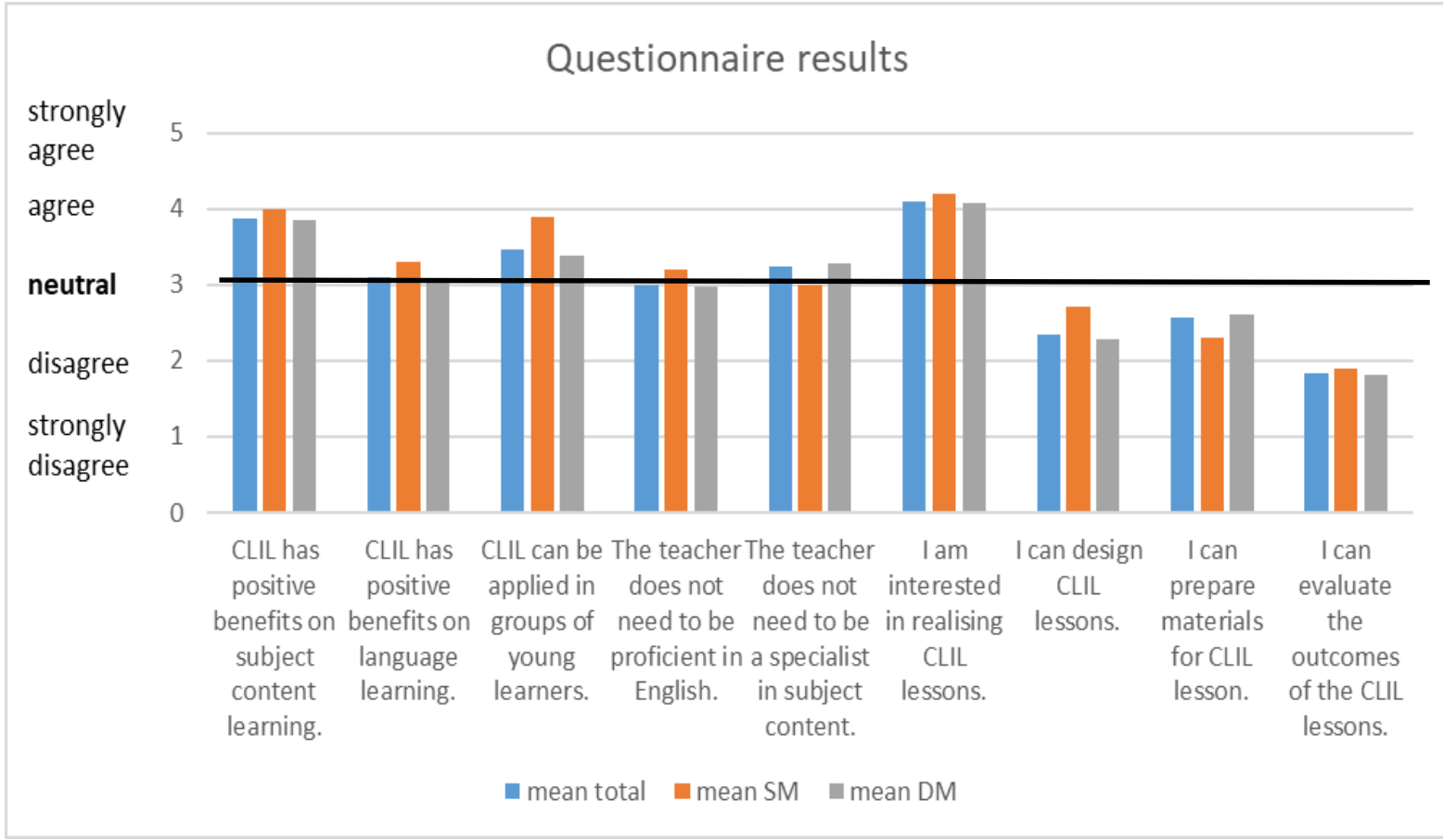

Figure 3 Questionnaire of student teachers' attitudes to content and language integrated learning

As it can be seen from the table 2, students believe in benefits of CLIL, mainly in subject learning and they are positively oriented towards CLIL lessons and would like to realise CLIL lessons. On the other hand, they are not persuaded about their abilities to design CLIL lessons (2,35), to prepare CLIL materials $(2,89)$ and to asses students $(1,82)$. It would be interesting to discuss the same issues with the teachers in practice who already have experience with CLIL. In all 
questions but one (about the CLIL materials preparation) single major students were more confident, what can be explained by the fact they all passed the course on CLIL. On the other hand, even though they passed the course they fee no confidence in designing CLIL lessons and creating materials as well as assessing students. To make the results more transparent data are displayed in the figure 3.

\section{Conclusion}

There are many factors affecting the success of (language) teaching and learning. Students and their motivation, teacher, methods, materials, etc. Universities have big power to prepare good teachers who not only teach (a textbook) but are creative enough to create own materials to tailor them to meet the learners' needs, cooperative enough to work with colleagues on planning CLIL lessons and preparing material that fit the set aims. Universities should be ready to address the needs of practice, needs of students and if possible to influence students attitudes. Data indicated that even though pre-service teachers are positive about CLIL application and are interested in realising CLIL lessons they do not feel confident especially in evaluating the outcomes of CLIL lessons and creating materials for CLIL lessons. Interestingly, data suggest that preservice teachers are less confident in the tasks that require creativity.

There are serious limitations of the study; firstly the group was not consistent (there were students who passed the course on CLIL compulsory course, there was a group of students who passed the course on CLIL as a compulsory-optional course and there was a group of students who did not attend the course. What more, they have no or very short experience with CLIL application.

If there is a decision to apply CLIL top-down systematically, the universities have to include CLIL methodology into their curricula. This, however, should become a part of not only language teaching curricula but also content subject curricula.

\section{Acknowledgement}

This study derived from a governmentally-funded research project financed by the Slovak Ministry of Education, Science, Research and Sport (research grant number KEGA project 032PU-4/2019, project: Vytvorenie učebných materiálov pre učitel'ov ZŠ pre integrovanie jazykového a obsahového vyučovania). 


\section{References}

Agudo, J.D.D.M. (2019). Which instructional programme (EFL or CLIL) results in better oral communicative competence? Updated empirical evidence from a monolingual context. Linguistics and Education, 51, 69-78. doi: 10.1016/j.linged.2019.04.008

Alonso, A.C. (2015). Receptive Vocabulary of CLIL and Non-CLIL Primary and Secondary School Learners. Complutense Journal of English Studies, 23(0). doi: 10.5209/rev_cjes.2015.v23.51301

Bruton, A. (2013). CLIL: Some of the reasons why ... and why not. System, 41(3), 587-597. doi: 10.1016/j.system.2013.07.001

C4C - CLIL for Children. (2016). State of art report about use of CLIL methodology in primary schools. Retrieved from http://www.clil4children.eu/documents-and-media/state-of-artreport-about-use-of-clil-methodology-in-primary-schools/

Cañado, M.L.P. (2016). From the CLIL craze to the CLIL conundrum: Addressing the current CLIL controversy. Bellaterra Journal of Teaching \& Learning Language \& Literature, 9(1), 9-31. doi: 10.5565/rev/jtl3.667

Cañado, M.L.P. (2018). The effects of CLIL on L1 and content learning: Updated empirical evidence from monolingual contexts. Learning and Instruction, 57, 18-33. doi: 10.1016/j.learninstruc.2017.12.002

Chostelidou, D., \& Griva, E. (2014). Measuring the Effect of Implementing CLIL in Higher Education: An Experimental Research Project. Procedia - Social and Behavioral Sciences, 116, 2169-2174. doi: 10.1016/j.sbspro.2014.01.538

Coyle, D. (2007). Content and Language Integrated Learning: Towards a Connected Research Agenda for CLIL Pedagogies. International Journal of Bilingual Education and Bilingualism, 10(5), 543-562. doi: 10.2167/beb459.0

Coyle, D., Hood, P., \& Marsh, D. (2010). Clil - Content and language integrated learning. Cambridge: Cambridge University Press.

Darn, S. (2006, January 10). Content and Language Integrated Learning (CLIL): A European Overview. Online Submission. Retrieved December 26, 2019, from https://files.eric.ed.gov/fulltext/ED490775.pdf

Isidro, X.S., \& Lasagabaster, D. (2018). The impact of CLIL on pluriliteracy development and content learning in a rural multilingual setting: A longitudinal study. Language Teaching Research, 23(5), 584-602. doi: 10.1177/1362168817754103

Jäppinen, A.-K. (2005). Thinking and Content Learning of Mathematics and Science as Cognitional Development in Content and Language Integrated Learning (CLIL): Teaching Through a Foreign Language in Finland. Language and Education, 19(2), 147-168. doi: 10.1080/09500780508668671

Marsh, D., \& Frigols Martín, M. (n.d.). ntroduction: Content and Language Integrated Learning. Retrieved December 26, 2019, from https://www.uni-due.de/imperia/md/ content/appliedlinguisticsdidactics/lingon/marsh_frigols_clil_intro_ts_me.pdf.

Mehisto, P. (2012). Criteria for producing CLIL learning material. Encuentro, 21, 15-33.

Morton, T. (2013). Critically Evaluating Materials for CLIL: Practitioners' Practices and Perspectives. In Grey (ed.) Critical Perspectives on Language Teaching Materials, 111-136. doi: 10.1057/9781137384263_6

Piesche, N., Jonkmann, K., Fiege, C., \& Keßler, J.-U. (2016). CLIL for all? A randomised controlled field experiment with sixth-grade students on the effects of content and language integrated science learning. Learning and Instruction, 44, 108-116. doi: 10.1016/j.learninstruc.2016.04.001 
SOCIETY. INTEGRATION. EDUCATION

Proceedings of the International Scientific Conference. Volume I, May $22^{\text {th }}-23^{\text {th }}$, 2020. 86-96

Pokrivčáková, S. (2013). Quality Survey of Slovak Teachers’ Personal Views on Content Language Integrated Learning (CLIL). International Journal of Liberal Arts and Social Science, 1(1), 83-93.

Pokrivčáková, S. (2015). CLIL in Slovakia: projects, research, and teacher training (20052015). In: CLIL in Foreign Language Education: e-textbook for foreign language teachers. Nitra: UKF, pp. 17-29.

Pokrivčáková, S., Menzlová, B., \& Farkašová E. (2010). Creating conditions for effective application of CLIL methodology in Slovakia. In: Modernization of Teaching Foreign Languages: CLIL, Inclusive and Intercultural Education. Brno: Masarykova univerzita, pp. 23-28

Ouazizi, K. (2016). The Effects of CLIL Education on the Subject Matter (Mathematics) and the Target Language (English). Latin American Journal of Content \& Language Integrated Learning, 9(1), 110-137. doi: 10.5294/laclil.2016.9.1.5

Ranjit, S. (2000). How to Develop and Produce Simple Learning Materials with Limited Resources at Community Level. Preparation of Continuing Education Materials in Rural Areas in Asia and the Pacific, the 18th Regional Workshop. Retrieved December 30, 2019, from http://www.accu.or.jp/litdbase/pub/dlperson/pdf0106/rpp25.pdf.

Scott, A.G. (2009). CLIL: An interview with Professor David Marsh. IH Journal of Education and Development, Spring (26), 8-10. Retrieved from http://ihjournal.com/wpcontent/uploads/journal/IHJournalIssue26Final.pdf

Sepešiová, M. (2015). CLIL lesson planning. In: Modernization of Teaching Foreign Languages: CLIL, Inclusive and Intercultural Education. Brno: Masarykova univerzita, pp. 131-152

Straková, Z. (2015). CLIL at lower secondary level. In: Modernization of Teaching Foreign Languages: CLIL, Inclusive and Intercultural Education. Brno: Masarykova univerzita, pp. 60-76

Tomlinson, B. (2010). Principles and procedures of materials development. In Harwood, N. (Ed.) English Language Teaching Materials: Theory and Practice (pp. 81-108). Camabridge University Press.

Vilkancienè, L., \& Rozgienè, I. (2017). CLIL Teacher Competences and Attitudes. Sustainable Multilingualism, 11(1), 196-218. doi: 10.1515/sm-2017-0019

Zarobe, Y.R.D., \& Cenoz, J. (2015). Way forward in the twenty-first century in content-based instruction: moving towards integration. Language, Culture and Curriculum, 28(1), 90-96. doi: 10.1080/07908318.2014.1000927 